\title{
Efficacy of Micro Algae and Thyme Essential Oil in the Management of Alternaria Leaf Spot of Broccoli (Brassica oleracea var. italica)
}

\author{
K. V. Madhavi Latha* and Abhilasha A. Lal \\ Department of Plant Pathology, Naini Agricultural Institute, Sam Higginbottom University of \\ Agriculture Technology and Sciences, Prayagraj and Uttar Pradesh, India. \\ *Corresponding author
}

\section{A B S T R A C T}

\begin{tabular}{l} 
Ke y w o r d s \\
Microalgae, Thyme \\
essential oil, \\
$\begin{array}{l}\text { Alternaria leaf spot, } \\
\text { Alternaria } \\
\text { brassicae, Broccoli }\end{array}$ \\
\hline Article Info \\
$\begin{array}{l}\text { Accepted: } \\
\text { 04 December } 2020 \\
\text { Available Online: } \\
\text { 10 January } 2021\end{array}$ \\
\hline
\end{tabular}

\section{Keywords}

Microalgae, Thyme essential oil,

Alternaria leaf spot Alternaria

Article Info

Accepted:

Available Online:

10 January 202
Broccoli (Brassica oleracea var. italica) is a member of 'Cole crop group' closely related to cabbage, cauliflower, kale and mustard it belongs to the family Brassicaceae. Alternaria leaf spot caused by Alternaria brassicae is serious disease in broccoli growing areas and occurs as a pre-harvest as well as post-harvest brown to black spots appears on the head of the broccoli. Thyme essential oil was tested in-vitro at different concentrations viz., $0.25 \%$, $0.5 \%, 0.75 \%, 1 \%$, and mancozeb $0.1 \%$ against radial growth of Alternaria brassicae. The minimum radial growth $(\mathrm{mm})$ at $120 \mathrm{hrs}$ was observed at a concentration of thyme essential oil @ 1.0\%(5.213 mm) followed by thyme essential oil @0.75\% (7.517 mm). The maximum percentage inhibition at 120 hrs was observed in thyme essential oil @ $1.0 \%(94.20 \%)$ followed by thyme essential oil @ $0.75 \%(91.30 \%)$ as compared to treated check mancozeb @ 0.0.1\% (90\%) and untreated check $(0.00 \%)$ under in-vitro conditions. The microalgae and thyme essential oil were tested under field conditions during Rabi 2019- 2020 for their efficacy against the disease, plant growth \& yield parameters. Among the treatments the maximum plant height $(\mathrm{cm})$ at 90 DAT (Days after transplanting) $(36.25$ $\mathrm{cm})$, maximum number of leaves at 90 DAT (17.25), minimum disease intensity (\%) at 60 DAT $(21.97 \%)$,maximum head weight $(\mathrm{t} / \mathrm{ha})(11.41 \mathrm{t} / \mathrm{ha})$, maximum root length $(\mathrm{cm})$ $(14.04 \mathrm{~cm})$ and maximum yield (t/ha) (13.76 t/ha) was recorded in $\mathrm{T}_{3}-$ microalgae @ 4kg/ha + thyme oil @1.0\%followed by $\mathrm{T}_{2}-$ microalgae @ 3kg/ha + thyme oil @ 1.0\% as compared to untreated check control T0.Higher gross return value (Rs. 2,75,560/ha), net return value (Rs. 1,03,195/ha), and B:C Ratio (2.67) was found in the treatment T3 microalgae@4 kg/ha + thyme oil @1.0\% as compared to untreated check control T0 (1.64).

\section{Introduction}

Broccoliis a member of "Colecrop group" closely related to cabbage, cauliflower, kale and mustard. Belongs to the family Brassicaceae. It is botanical classified as a variety of Brassica oleracea species. The word broccoli comes from Italian word broccolo, which means "flowering crest of a cabbage". It is highly nutritious crop containing high number of vitamins (A and $\mathrm{C}$ ) and minerals (K, P, $\mathrm{Ca}$ and $\mathrm{Fe}$ ). Moreover, it also contains thiamine, riboflavin and niacin. Broccoli is the richest source of protein among colecrops 
(Allen and Allen, 2007). Broccoli is a cool season vegetable thrives best in cool and moist climate. It is much sensitive to very low and high temperature. Broccoli grows best when exposed to an average daily temperature between 17 and $23{ }^{\circ} \mathrm{C}$. Broccoli is now growing in many countries like china, USA, UK, India, Pakistan, France, Italy, and Mexico. World's top producer of Broccoli and cauliflower in 2018-19 are China $9,7,65,700 \mathrm{MT}$ and India $8,7,68,900 \mathrm{MT}$ in worlds total production of 5,87,51,856MT. (FAO, United Nations). China is first in area of cauliflower and broccoli in 2018-19 having $7,80,600 \mathrm{ha}$ followed by India(6,24,900ha) and $\operatorname{Spain}(2,10,000 \mathrm{ha})$. In India broccoli is mainly grown in Uttar Pradesh, Jammu and Kashmir. In Maharashtra also broccoli grown at some important places like Pune, Nasik.

Alternaria leaf spot is caused by Alternaria brassicae in cruciferous crops is common in which leaf spot reduces plant vigour, affect the edible flower part of broccoli head. This leaf spot occurs during warm, moist conditions. On older plants, the bottom leaves are infected first with brown circular spots on the leaves. Leaf spot of broccoli has been possessing serious problem to the low productivity and causing yield loss up to 23$30 \%$ in India. The symptoms of Alternaria leaf spot were observed in the field 20 days after transplanting. The typical symptoms appear as circular to irregular shaped spots with concentric rings (target board appearance). Individual spots coalesce into large necrotic areas and leaf drop can occur. Lesions can occur on petioles, stems, flower pedicels on broccoli plant (Ellis, 1968).

Essential oils are the complete mixture of volatile substances generally present in leaves at low concentration. Before such substances can be analyzed, they have to be extracted from matrix, using dried plant material. Several methods can be employed for this purpose e.g. Hydro distillation method, steam distillation method, Soxhlet apparatus and simultaneous distillation extraction. Microalgae are used in agriculture in different applications, such as amendment, foliar application and seed priming. Microalgal biostimulants are able to stimulate the growth and development of several crops under both optimal and stressful condition. It generating multiple benefits, such as enhanced rooting, higher crop yields and quality and tolerance to drought and salt (Domenico, 2019).

One such attempt as been made to evaluate the effect of microalgae and thyme essential oil against Alternaria leaf spot of broccoli (Alternaria brassicae) both in-vitro and invivo conditions.

\section{Materials and Methods}

\section{Experimental site}

The laboratory experiment was conducted at the laboratory of the Department of Plant Pathology and field experiment was carried out at the central research field, Sam Higginbottom University of Agriculture and Sciences, Prayagraj. The experiment was conducted during Rabi season 2019 - 2020.

\section{Isolation of pathogen}

For the isolation of the pathogen associated with the symptoms on leaf spot portions were cut into suitable pieces and washed thoroughly in tap water so as to remove soil and other adherent particles. The pieces were then disinfected by $0.01 \%$ sodium hypo chloride solution for one minute followed by rinsing in three changes of sterilized water to remove the traces of sodium hypo chloride solution and were dried on sterilized blotting paper, three to four such pieces were then placed aseptically on sterilized PDA medium in each petri plate of two types of 
symptomatic pieces. The petri plates were incubated at room temperature $\left(28+-1^{\circ} \mathrm{C}\right)$, soon as growth of fungus was noticed, well isolated fungal growth free from contamination was transferred to agar slants by hyphal tip technique. The test isolates of the pathogen were aseptically sub cultured, purified and maintained separately on agar slant tubes in refrigerator for further studies. The fungus culture thus obtained were then sub cultured on PDA slants and incubated in BOD incubator $(25=-2 C)$ for $2-4$ days. Such slants with good fungal growth were preserved in refrigerator at $5+-1 \mathrm{C}$.

\section{Identification of the fungus cultures}

The study was undertaken to confirm the isolated pathogen. Identification of the fungus was made after examining conidia under microscope from pure culture of the test fungus. These observations were compared with those of the standard measurements and characteristics, pathogenicity test and the microscopic observation, test fungus as identified as Alternaria brassicae causing leaf spot of broccoli (Sharma et al., 2013).

\section{Morphological characters}

Morphology of the fungus was studied of 510 days old culture grown on PDA medium by adoption of slide culture technique. Morphological characters viz, septation, shape of conidia and beak size were recorded under compound microscope (40x).

\section{Poisoned food technique}

In poison food technique the following treatments were used $\mathrm{T}_{0}$ control, $\mathrm{T}_{1}$-Thyme oil@0.25\%, $\mathrm{T}_{2}$-Thyme oil @0.5\%, $\mathrm{T}_{3}$ Thyme oil @0.75\%, T 4 -Thyme oil @1.0\%, $\mathrm{T}_{5}$-Mancozeb @ 0.01\%. Five mm diameter of culture disc of Alternaria brassicae was kept at the center of each Petri plate containing the essential oil of required concentrations dissolved in PDA media. Three replications were maintained. The plates will be incubated at $27^{\circ} \mathrm{C}$ for two days and colony diameter was recorded. Percent mycelia growth inhibition of test fungus over untreated control was calculated by using the formula.

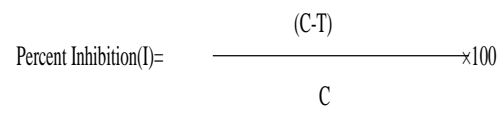

Where,

$\mathrm{C}=$ Growth $(\mathrm{mm})$ of the test fungus in untreated control plate.

$\mathrm{T}=$ Growth $(\mathrm{mm})$ of the test fungus in treated control.

\section{Observations recorded}

Pre-harvest and post-harvest observations were recorded during the course of experiment.

\section{Post-harvest observations}

1) Head weight $(\mathrm{Kg})$ was recorded after harvest of crop.

2) Total yield $\left(\mathrm{t} / \mathrm{ha}^{-1}\right)$

\section{Results and Discussion}

Effect of thyme essential oil and fungicide on radial mycelial growth $(\mathrm{mm})$ and percent inhibition of Alternaria brassicae at $120 \mathrm{hrs}$

The minimum mycelia growth and percent inhibition was recorded in T4 - thyme oil @ $1.0 \%$ (5.21 mm and $94.20 \%)$ followed by T3 - thyme oil @0.75\%(7.51 mm and 91.30\%), T2 - thyme oil @ $0.5 \%$ (22.70 mm and 75.75\%), T1 - thyme oil @ $0.25 \%$ (32.0 $\mathrm{mm}$ and 67\%) as compared to T5 - mancozeb (treated check) @ 0.0.1\% (8.98 mm) and T0 - 
untreated check with $(91.66 \mathrm{~mm}$ and $90 \%)$. Among the treatments (T4, T3) were nonsignificant over $\mathrm{T} 5$, and (T5, T2), (T4, T3), (T3, T2) were significant and (T1, T0).

\section{Disease intensity of broccoli}

The minimum disease intensity (\%) was recorded in T3 - microalgae @ $4 \mathrm{~kg} / \mathrm{ha}+$ thyme oil @1.0\% (21.97), followed by T2 microalgae@3 kg/ha + thyme oil@1.0\%
(22.83), T4 - microalgae @ 5 kg/ha + thyme oil @1.0\% (26.12), T5 - microalgae @6 kg/ha + thyme oil @1.0\% (27.04), T6 microalgae@7 kg/ha + thyme oil @1.0\% (29.04), T1 - microalgae @ 2 kg/ha + thyme oil @1.0\% (30.96) and highest disease intensity was found in untreated control T0 (33.02).Among the treatments (T1, T2, T3, $\mathrm{T} 4, \mathrm{~T} 5, \mathrm{~T} 6)$ were found to be non-significant over untreated control T0 (Table 1 and 2).

Table.1 Effect of thyme essential oil and fungicide on radial mycelial growth ( $\mathrm{mm}$ ) and percent inhibition of Alternaria brassicae at 48, 72, 96 and 120hrs

\begin{tabular}{|c|c|c|c|c|c|c|}
\hline \multirow{2}{*}{ S. No } & Treatments & \multicolumn{3}{|c|}{ Radial growth (mm) } & \multirow{2}{*}{$\begin{array}{c}\text { Percent } \\
\text { inhibition }\end{array}$} \\
\hline T0 & Control (untreated check) & $48 \mathrm{Hrs}$ & $72 \mathrm{Hrs}$ & $96 \mathrm{Hrs}$ & $120 \mathrm{Hrs}$ & $0 \%$ \\
\hline T1 & Thyme oil @ 0.25\% & 8.75 & 56.76 & 67.40 & 91.66 & $67 \%$ \\
\hline T2 & Thyme oil @ 0.5\% & 6.09 & 8.33 & 8.6 & 22.70 & $75.75 \%$ \\
\hline T3 & Thyme oil @ 0.75\% & 3.47 & 5.61 & 6.62 & 7.51 & $91.30 \%$ \\
\hline T4 & Thyme oil @ 1.0\% & 1.93 & 3.27 & 4.15 & 5.2 & $94.20 \%$ \\
\hline T5 & Mancozeb (Treated check) & 2.88 & 4.29 & 7.8 & 8.9 & $90 \%$ \\
\hline & F test & S & S & S & S & - \\
\hline & S. Ed. $( \pm)$ & 0.40 & 0.43 & 0.58 & 0.64 & - \\
\hline & C.D. (at 5\%) & 0.89 & 0.96 & 1.28 & 1.42 & - \\
\hline
\end{tabular}

Table.2 Effect of microalgae and thyme essential oil on disease intensity of broccoli at 30, 45, 60 DAT, head weight, and total yield in vivo conditions

\begin{tabular}{|c|c|c|c|c|c|c|}
\hline \multirow[b]{2}{*}{ S. No } & \multirow[b]{2}{*}{ Treatments } & \multicolumn{3}{|c|}{ Disease intensity } & \multirow{2}{*}{$\begin{array}{l}\text { Head } \\
\text { weight }\end{array}$} & \multirow{2}{*}{$\begin{array}{l}\text { Total } \\
\text { yield }\end{array}$} \\
\hline & & 30 DAT & 45 DAT & $\begin{array}{l}60 \\
\text { DAT }\end{array}$ & & \\
\hline T0 & Control (untreated check) & 24.98 & 28.03 & 33.02 & 8.00 & 7.70 \\
\hline T1 & Microalgae + Thyme essential oil & 22.29 & 25.83 & 30.96 & 8.56 & 8.40 \\
\hline T2 & Microalgae + Thyme essential oil & 18.16 & 21.28 & 22.83 & 10.54 & 12.13 \\
\hline T3 & Microalgae + Thyme essential oil & 15.35 & 19.07 & 21.97 & 11.41 & 13.7 \\
\hline T4 & Microalgae + Thyme essential oil & 19.14 & 22.86 & 26.12 & 10.25 & 11.10 \\
\hline T5 & Microalgae + Thyme essential oil & 20.55 & 23.62 & 27.04 & 9.80 & 10.20 \\
\hline \multirow[t]{4}{*}{ T6 } & Microalgae + Thyme essential oil & 21.53 & 24.59 & 29.04 & 9.55 & 9.26 \\
\hline & F test & $S$ & $S$ & $S$ & $S$ & $\mathbf{S}$ \\
\hline & S. Ed. $( \pm)$ & 0.253 & 0.42 & 0.56 & 0.16 & 0.36 \\
\hline & C.D. (at 5\%) & 0.55 & 0.94 & 1.24 & 0.37 & 0.80 \\
\hline
\end{tabular}




\section{Head weight $(\mathrm{t} / \mathrm{ha})$ of broccoli}

The maximum head weight of broccoli was recorded in treatment T3 - microalgae @ 4 $\mathrm{kg} / \mathrm{ha}+$ thyme oil @ 1.0\% (11.41 t/ha) followed by T2 - microalgae @ $3 \mathrm{~kg} / \mathrm{ha}+$ thyme oil @ $1.0 \% \quad(10.54$ t/ha), T4 microalgae @ $5 \mathrm{~kg} / \mathrm{ha}+$ thyme oil @ $1.0 \%$ (10.25 t/ha) and T5 - microalgae @ 6 kg/ha + thyme oil @ 1.0\% (9.80 t/ha), T6 - microalgae @ $7 \mathrm{~kg} / \mathrm{ha}+$ thyme oil @ 1.0\% (9.55 ton/ha), T1-microalgae @ 2 kg/ha + thyme oil @ $1.0 \%(8.56 \mathrm{t} / \mathrm{ha})$ as compared to untreated control T0 - (8.00t/ha).Among the treatments (T1, T2, T3, T4, T5, T6) were found significant over untreated control T0. The treatments (T3, T4), (T4, T5) and (T5, T6) were found non-significant to each other.

\section{Total yield (t/ha) of broccoli}

The highest total yield of broccoli was recorded in treatment T3 - microalgae @ 4 $\mathrm{kg} / \mathrm{ha}+$ thyme oil @1.0\% (13.76 t/ha) followed by T2 - microalgae @ $3 \mathrm{~kg} / \mathrm{ha}+$ thyme oil @ $1.0 \% \quad(12.13$ t/ha $), \quad \mathrm{T} 4$ microalgae@5 kg/ha + thyme oil @1.0\% (11.10 t/ha) and T5 - microalgae @ 6 kg/ha + thyme oil @1.0\% (10.20 t/ha), T6 microalgae@7 kg/ha + thyme oil @1.0\% (9.22 t/ha), T1 -microalgae @ $2 \mathrm{~kg} / \mathrm{ha}+$ thyme oil @ $1.0 \%$ (8.40 t/ha) as compared to untreated control T0 - (7.70t/ha). Among the treatments $(\mathrm{T} 1, \mathrm{~T} 2, \mathrm{~T} 3, \mathrm{~T} 4, \mathrm{~T} 5, \mathrm{~T} 6)$ were found significant over untreated control T0 (control + FYM). The treatments (T0, T1) and (T1, T6) were found non-significant to each other.

Probable reasons for such findings may be the anti-fungal activity of thyme oil against the tested fungi Alternaria brassicae. The largest antifungal activity of thyme essential oil was observed at concentration @ 1.0\%. Thyme essential oil may be apparently the best inhibitors for fungal pathogen because of the presence of phenolic compounds such as carvacrol and thymol as main constitutes which might disrupt the fungal cell membrane. Microalgae used as amendment, foliar application, and seed priming used in conjunction with synthetic fertilizers, crop protection products and plant growth regulators, generating multiple benefits like enhanced rooting, head weight, higher crop yields and quality and tolerance to drought and salt and essential oils give protection to the plants against invasion of leaf spot pathogen.

In conclusion the results revealed that maximum inhibition percentage was recorded at thyme essential oil @ 1.0\% was found most effective against Alternaria brassicae causing Alternaria leaf spot of broccoli under in vitro conditions.

In vivo studies revealed that minimum disease intensity (\%) in broccoli at 30, 45, 60 DAT, the maximum head weight (t/ha), and maximum total yield $(\mathrm{t} / \mathrm{ha})$ were recorded in treatment T3 - Microalgae @4 kg/ha + Thyme essential oil @1.0\%.The findings of the present experiment are limited to one crop season (December 2019 to March 2020) under Prayagraj Agro- climatic conditions, as such to validate the present findings more such trials should be carried out in future.

\section{References}

Abd-AllA, M.A., Abd- El- Kader, M.M., Abd-ElKareem, F. and El Mohamedy, R. S. R (2011). Evaluation of lemongrass, thyme and peracetic acid against gray mould of strawberry fruits. Journal of Agricultural Technology. 7:1775-1787.

Abdel-Raouf, N., Al-Hamadian, A. A., and Ibraheem, I.B. (2012). Agricultural importance of algae. African Journal of Biotechnology. 11: 11648 -11658.

Aboomer, Safder, M.W., Usman, M., Iqbal, S., Abbas, M.H., Anum, H., Firdous, H. and Sarwar, M.I. (2019). Epidemiological 
factors increasing the Alternaria leaf spot of cabbage and their management strategies. The International journal of biological research. 2: 2618 -1444.

Amein, T., Sandra, A.I., Wikstrom, M., Koch, E., Schmitt, A., Stephan, D., Jahn, M., Tinivella, F., Gullino, M.L., Forsberg, G., Werne, S., Wolf, J.D. and Groot, S.P.C. (2011) Evaluation of non-chemical seed treatment methods for control of Alternaria brassicicola on cabbage seeds. Journal of Plant Diseases and Protection. 118: 214- 221.

Arroussi, N. E., Redouane, B., Meftah., Najib, B., Abedelaziz, S. and Imane, W. (2016). Microalgae polysaccharides a promising plant growth bio stimulant. Journal of Algal Biomass Utlilization. 7 (4):55-63.

Asim, M., Iftikhar, Y., Arshad, M., Bashir, S., Raza1, M., Bilal, S. and Bakhtawar, F. (2019). Inhibitory effect of various fungicides on mycelial growth of Alternaria alternate cause of Alternaria leaf spot disease on Rosa Indica L.in Pakistan. Asian J Agric \& Biol. 7 (3):474481.

Berkeley, M.J. (1836). Fungi. (Ed. Smith, J.E.). The English Flora. 1: 339. Dey, P.K. (1948).

El-Awady, A.A., Saber, I.A., Nabil, M., Hamid, A. and Hassan, A.H. (2016). Increasing antioxidant content of broccoli sprouts using essential oils during cold storage. Agriculture (Polnohospodarstvo). 62 (3): 111-126.

Ellis, M.B. (1971). Dematiaceous hyphomycetes. Commonwealth Mycological Institute. Pp. 464- 497.

Feng, W. and Zheng, X. (2007). Essential oils to control Alternaria alternata in vitro and in vivo. Food Control. 18: 1126-1130.

Joly, P. (1959). Bull. Soc. Mycol. Fr. 75: 149-158.

Kadam, V.A., Dhutraj, D.N. and Pawar, D.V. (2018). In vitro evaluation of Different Fungicides against Alternaria alternate Causing Leaf and Fruit Spot in Pomegranate. International Journal of Current Microbiology and Applied Sciences. 7(10): 2319-7706.

Kiran, G.V.N.S.M., Thara, S.S. and Brinda, G.B. (2018). In vitro Efficacy of Fungicides against Alternaria brassicicola Causing Alternaria Leaf Spot of Cabbage. Int. J. Curr. Microbiol. App. Sci. 7(4): 11311135.

Kuldeep, S., Abhilasha, A. Lal., Kumar, D. and Meena, N.K. (2017). Evaluation of Selected Bio Agents, Plant extracts and Fungicides for the Management of Alternaria Leaf Blight of Indian Mustard. Int. J. Curr. Microbiol. App.Sc. 6 (4):2631.

Liu, Y., Xu, Z., Zhu, P., Liu, Y., Zhang, Z., Xu, L. and Toyoda, H. (2009). Postharvest Black Spot Disease in Broccoli Caused by Alternaria brassicicola. Ann. Rept. Kansai Pl. (51): 11-15.

Manjhi, P., Tomar, D.S. and Nayak, M.K. (2019). Efficacy of botanicals and chemical fungicide on development of Alternaria blight of mustard (Brassica juncea) and their economics. Annals of Plant and Soil Research. 21(4): 351-355.

Mason, E.W. (1928). Annotated account of fungi received at the Imperial Bureau of Mycology. I \& II (Fascicles). Pp. 34.

Meena, P.D., Awasthi, R.P., Chattopadhyay, C., Kolte, S.J. and Arvind Kumar. (2010). Alternaria blight: a chronic disease in rapeseed-mustard. Journal of Oilseed Brassica. 1 (1): 1-11.

Mendivil, E.A.S., Rodriguez, J.F.M., Espinosa, M.E., Fajardo, J.A.G.N and Vazquez, E.N.O. (2006). Chemical composition and fungicidal activity of the essential oil of thymus vulgaris against Alternaria citri. Chemical composition and fungicidal Soto. M. E et.al. 4: 1665-5745.

Mona., Ragab, M. M., Ashour A. M. A., AbdelKader, M. M., El-Mougy, N. S. and Abdel A, A. (2016). Fungicidal and Fungistatic Activity of Some Plant Essential Oils against Alternaria solani the Causal of Tomato Early Blight. Research Journal of Pharmaceutical, Biological and Chemical Sciences. 7(4): 0975-8585.

Oancea, F., Velea, S., Fătu, V., Mincea, C. and Ilie, 1. (2013). Microalgae-based plant bio stimulant and its effect on water stressed tomato plants, Romanian journal of plant protection. vi: 104. 
Pawar, V. C. and Thaker, E.V. S. (2006). Evaluation of the anti - Fusarium oxysporumf. spcicerand anti - Alternaria porri effects of some essential oils. World Journal of Microbiol Biotechnol.

Pedras, M.S.C., Zaharia, I.L., Gai, Y., Zhou, Y., and Ward, D.E. (2001). In planta sequential hydroxylation and glycosylation of a fungal phytotoxin: avoiding cell death and overcoming the fungal invader. Proc. Natl. Acad. Sci. 98: 747-52.

Plant Pathology. Adm. Rep. Agric. Dept. U.P. 47:39- 42 .

Prasad, B.V.S., Bhattiprolu, S. L., Kumari, V. P and Kumar, P.A. (2018). In Vitro Evaluation of Fungicides against Alternaria macrospora Causing Leaf Spot in Cotton. International Journal of Current Microbiology and Applied Sciences. 7(1): 2319-7706.

Riccioni, L. and Orzali, L. (2011). Activity of Tea Tree (Melaleuca alternifolia, Cheel) and thyme (Thymus vulgaris, Linnaeus.) Essential Oils against Some Pathogenic Seed Borne Fungi. Journal of Essential Oil Research.23.

Sailaja, S., Abhilasha, A. Lal. and Simon, S. (2017). Comparative efficacy of bio agents, botanicals and fungicides against alternaria leaf spot (Alternaria brassicae) of cauliflower (Brassica oleracea var. botrytis). Journal of Pharmacognosy and Phytochemistry. 6: 519-521.

Sharma, M., Deep, S., Bhati, D.S., Chowdappa, P., Selvamani, R. and Sharma, P. (2013). Morphological, cultural, pathogenic and molecular studies of Alternaria brassicae infecting cauliflower and mustard in India. African Journal of Microbiology Research. 7(26): 3351-3363.
Singh, V., Shrivastava. A., Jadon, S., Wahi, N., Singh, A. And Sharma, N. (2015). Alternaria disease of vegetable crops and its management control to reduce the low production. International Journal of Agriculture Sciences. 7: 837.

Tanovi, B., Gasic, S., Hrustic, J., Mihajlovic, M., Grahovac, M., Delibasic, G. and Stevanovic, M. (2013). Development of a Thyme Essential Oil Formulation and Its Effect on Monilinia fructigena. Pestic, Phytome. 28(4): 273-280.

Tarek, A. S. and El-Ramady, H. (2014). Effect of foliar application of bio-stimulants on growth, yield, components, and storability of garlic (Allium sativum L.), AJCS. 8: 271- 275.

Valvi, H.T., Kadam, J.J. and Bangar, V.R. (2019b). Isolation, Pathogenicity and Effect of Different Culture Media on Growth and Sporulation of Alternaria brassicae (berk.) Sacc. causing Alternaria Leaf Spot Disease in Cauliflower. International Journal of Current Microbiology and Applied Sciences. 8(4): 1900-1910.

Valvi, H.T., Saykar, A.D. and Bangar, V.R. (2019a). In vitro and in vivo field efficacy of different fungicides against Alternaria brassicae (Berk.) sacc. causing Alternaria leaf spot of cauliflower. Journal of Pharmacognosy and Phytochemistry. 8: 1333-1337.

Wagh, S.S., Suryawanshi, A.P. and Pawar, D.V. (2017). Efficacy of Fungicides, Bioagents and Phytoextracts against Alternaria carthami of Safflower in In Vitro Condition. Journal of Pure and Applied Microbiology. 11(3): 1589-1598.

\section{How to cite this article:}

Madhavi Latha, K. V. and Abhilasha A. Lal. 2021. Efficacy of Micro Algae and Thyme Essential Oil in the Management of Alternaria Leaf Spot of Broccoli (Brassica oleracea var. italica). Int.J.Curr.Microbiol.App.Sci. 10(01): 297-303.

doi: https://doi.org/10.20546/ijcmas.2021.1001.037 